\title{
甲状腺癌における頸部転移リンパ節の 超音波像の検討
}

\author{
千葉県がんセンター頭頸科

$\begin{array}{llllllllll}\text { 竹 内 } & \text { 洋 介 } & \text { 鈴 } & \text { 木 } & \text { 晴 } & \text { 彦 } & \text { 小 } & \text { 村 } & \text { 健 } \\ \text { 奥 村 一 } & \text { 彦 } & \text { 柳 } & \text { 井 } & \text { 智 } & \text { 恵 } & \text { 山 } & \text { 知 } & \text { 巳 } \\ & & & \text { 嶋 } & \text { 田 } & \text { 文 } & \text { 之 } & & & \end{array}$

\begin{abstract}
論文要旨
超音波検査による頸部リンパ節の質的診断のために, 甲状腺乳頭癌の転移性リンパ節39個と良性疾患の非 転移性リンパ節24個の超音波像を検討した。装置はアロカ社製 SSD-1200, 探触子は周波数 $10 \mathrm{MHz}$ メカニ カルセクタ型を使用した。転移性リンパ節は非転移性と比べ, 短径ではより厚く, 形状ではより球形を呈し ていた。内部エコーレベルは，転移性では等エコーから高エコーレベルのものが多かったのに対して，非転 移性では，高エコーレベルのものは認められず，低エコーレベルのものが多かった。点状エコーは，転移性 では79\%に認められたが，非転移性では認められなかった。線状エコーは，転移性リンパ節では認められな かったが，非転移性では $58 \%$ に認められた。襄胞性パターンは，転移性では $41 \%$ に認められたが，非転移性 では認められなかった。以上の結果は，超音波検査による頸部リンパ節の質的診断上，有用であると考えら れた。
\end{abstract}

Key words：超音波診断法（Ultrasonography)，頸部リンパ節（Cervical lymph node)，転移 (Metastasis), 甲状腺癌 (Thyroid cancer)

\section{緒言}

頸部リンパ節転移の有無の診断は頭頸部癌の治療方針 を決定する上で重要である。その診断法として丁寧な触 診が基本であることは勿論であるが，超音波診断法を用 いれば, 触診では得られないリンパ節内部の画像情報 （内部エコー）が容易に得られる。この画像情報を加味 することによって，より正確な診断が期待できる。従来， 扁平上皮癌の頸部転移りンパ節の超音波像に関する報 告 ${ }^{1-5)}$ は多いが, 甲状腺癌の頸部転移リンパ節の超音波 像に言及した報告 ${ }^{3,6}$ は少ない。

今回，われわれは，超音波診断法による甲状腺癌にお ける頸部転移リンパ節の質的診断を目的として，その超 音波像について検討したので報告する。

\section{対象および方法}

転移性リンパ節として，1994年 4 月より1996年 6 月ま での 2 年 2 か月間に, 千葉県がんセンターで頸部郭清術 を含む甲状腺切除手術を行なった甲状腺乳頭癌13例にお ける，未治療のリンパ節のうち，術前に超音波検査を施

別刷請求先:

干 260 千葉市中央区仁戸名町 666-2

千葉県がんセンター頭頸科

竹内洋介
行し, 郭清術後の病理組織学的検査で甲状腺乳頭癌の転 移陽性と診断された39個を対象とした。13例の性別は, 男性 5 例，女性 8 例であり，年齢構成は，47歳から78歳, 平均56歳であった。これに対して，非転移性リンパ節と して, 良性疾患 20 例において, 穿刺吸引細胞彮や摘出後 の病理組織学的検查で非転移性と診断されたリンパ節, もしくは，6か月以上の経過観察中に大きさが縮小した もの 24 個を対象とした。20例の疾患別内訳は，リンパ節 炎13例, 耳下腺多形腺腫 3 例, 甲状腺腫 2 例, 側頸囊胞 1 例，唾石症 1 例であった。また，20例の性別は，男性 4 例，女性16例であり，年齢構成は， 24 歳から 80 歳，平 均48歳であった。

超音波像の検討項目としては, リンパ節の大きさ，形 状，内部エコーの 3 項目について検討した。大きさは, リンパ節の長径と短径を超音波画像から計測した。長径 はリンパ節の最大面の最大径とし，短径はこの最大面に 直交する最大面の最小径とした。形状は，短径／長径比 を指標とした。この值が1.00に近いほどリンパ節の形状 は球形に近く，0に近いほど扁平であることになる。内 部エコーは，エコーレベル（輝度）を胸鎖乳突筋の横断 像のエコーレベルを基準として，高エコー，等エコー， 低エコーの3 段階に分けた。また, 点状エコー, 線状エ コー, 襄胞性パターンの有無について検討した。

超音波診断装置はアロカ社製 SSD-1200，探触子は 
周波数 $10 \mathrm{MHz}$ メカニカルセクタ型を使用した。統計学 的な有意差の検定には Mann-Whitney Test を用いた。

\section{結 果}

\section{1）大きさ（表 1)}

(1)長径

転移性リンパ節の長径は $5 \mathrm{~mm}$ から $60 \mathrm{~mm}$ の範囲 にあり，その中央值および平均值は，それぞれ $19.6 \mathrm{~mm}$, $20.0 \mathrm{~mm}$ であった。一方, 非転移性リンパ節では，長 径は $8 \mathrm{~mm}$ から $23 \mathrm{~mm}$ の範囲にあり，その中央值およ び平均值は，それぞれ $14.5 \mathrm{~mm}, 14.9 \mathrm{~mm}$ であった。 長径については, 転移性, 非転移性リンパ節間に統計学 的な有意差は認められなかった $(\mathrm{P}>0.50)$ 。

(2)短径

転移性リンパ節の短径は $3 \mathrm{~mm}$ から $42 \mathrm{~mm}$ の範囲に あり，その中央值および平均值は，それぞれ $9.0 \mathrm{~mm}$ ， $11.8 \mathrm{~mm}$ であった。一方，非転移性リンパ節では，短 径は $2 \mathrm{~mm}$ から $12 \mathrm{~mm}$ の範囲にあり, その中央值およ び平均值は，それぞれ $6.5 \mathrm{~mm}, 6.3 \mathrm{~mm}$ であった。短 径については, 転移性, 非転移性リンパ節間に統計学的 な有意差が認められた $(\mathrm{P}<0.0001)$ 。

2) 形状 (表 1)

転移性リンパ節の短径／長径比は 0.23 から 0.89 範囲 にあり，その中央值および平均值は，それぞれ0.60， 0.61であった。一方, 非転移性リンパ節では, 短径／長 径比は 0.18 から 0.73 範囲にあり，その中央值および平 均值は，それぞれ0.45，0.42であった。短径／長径比に ついては, 転移性, 非転移性リンパ節間に統計学的な有 意差が認められた $(\mathrm{P}<0.0001)$ 。

3）内部エコー（表 2)

(1)エコーレベル

転移性リンパ節では，等エコーレベルのもの（図 1A） が $61 \%$ と最も多く，次いで高エコーレベルのもの（図 $1 \mathrm{~B}, \mathrm{C}, \mathrm{D}) 26 \%$, 低エコーレベルのもの（図 1E） 13 \%であった。これに対して，非転移性リンパ節では，高 エコーレベルのものは認められず，転移性リンパ節で最 も多かった等エコーレベルのものは 8 \%と少なかった。 一方，転移性リンパ節では最も少なかった低エコーレベ ルもの（図 2）が92\%と大部分を占めた。

(2)点状エコー

転移性リンパ節では79\%（31/39）に認められたのに 対し, 非転移性では認められなかった（図 $1 \mathrm{~A}, \mathrm{~B}, \mathrm{C}$, D)。

(3)線状エコー

転移性リンパ節では認められなかったのに対し，非転 移性では $58 \%(14 / 24)$ ものリンパ節に認められた（図 2B)。
表 1 大きさ, 形状

\begin{tabular}{|c|c|c|c|}
\hline & 長径 (mm) & 短径 (mm) & 短径／長径比 \\
\hline 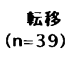 & $\begin{array}{c}5 \sim 60 \\
(19.6,20.0)\end{array}$ & $\begin{array}{c}3 \sim 42 \\
(9.0, \quad 11.8)\end{array}$ & $\begin{array}{c}0.23 \sim 0.89 \\
(0.60,0.61)\end{array}$ \\
\hline $\begin{array}{r}\text { 非芸移 } \\
(n=24)\end{array}$ & $\begin{array}{c}8 \sim 23 \\
(14.5 . \quad 14.9)\end{array}$ & $\begin{array}{c}2 \sim 12 \\
(6.5,6.3)\end{array}$ & $\begin{array}{c}0.18 \sim 0.73 \\
(0.45,0.42)\end{array}$ \\
\hline
\end{tabular}

(中央値，平均值)

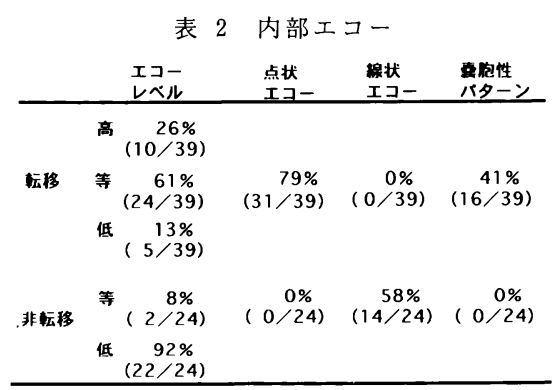

(4)襄胞性パターン

転移性リンパ節では $41 \%(16 / 39)$ に認められた（図 1A，C）が，非転移性では認められなかった。

\section{考察}

頭頸部癌における腫大した頸部リンパ節が，転移性で あるか非転移性であるかを診断することは，照射野や頸 部郭清範囲など治療方針を決定する上で重要である。超 音波診断法による頸部リンパ節の質的診断に関しては, 従来より多数の報告がある ${ }^{2,7-9)}$ 。しかし，未だにその診 断基準は確立されていない。以下に，超音波診断法にお ける質的診断基準の項目としてリンパ節の大きさ, 形状, 内部エコーについて述べる。

1) 大きさ

質的診断の基準として，短径を用いた報告が多い ${ }^{2,5,10)}$ 。 古川 ${ }^{21}$ は、リンパ節の大きさ，とくに“厚み”が質的診 断の最も良い指標になると述べている。この“厚み”は 本検討の短径にほほ相当すると思われる。さらに, 古川 は，“厚み”が $6 \mathrm{~mm}$ 以上のリンパ節を転移陽性とする ことによって，偽陽性率 $6 \%$, 偽陰性率 $12 \%$ と高い診断 率を得ている。また, 本検討では, 斉藤ら ${ }^{3)}$ の検討結果 と同様に, 転移性リンパ節の短径は, 非転移性リンパ節 の短径より統計学的に有意に厚かった。したがって、リ ンパ節の短径は, 質的診断の基準となると考えられる。 ただし，古川ら ${ }^{11}$ の指摘するように，質的診断の基準 


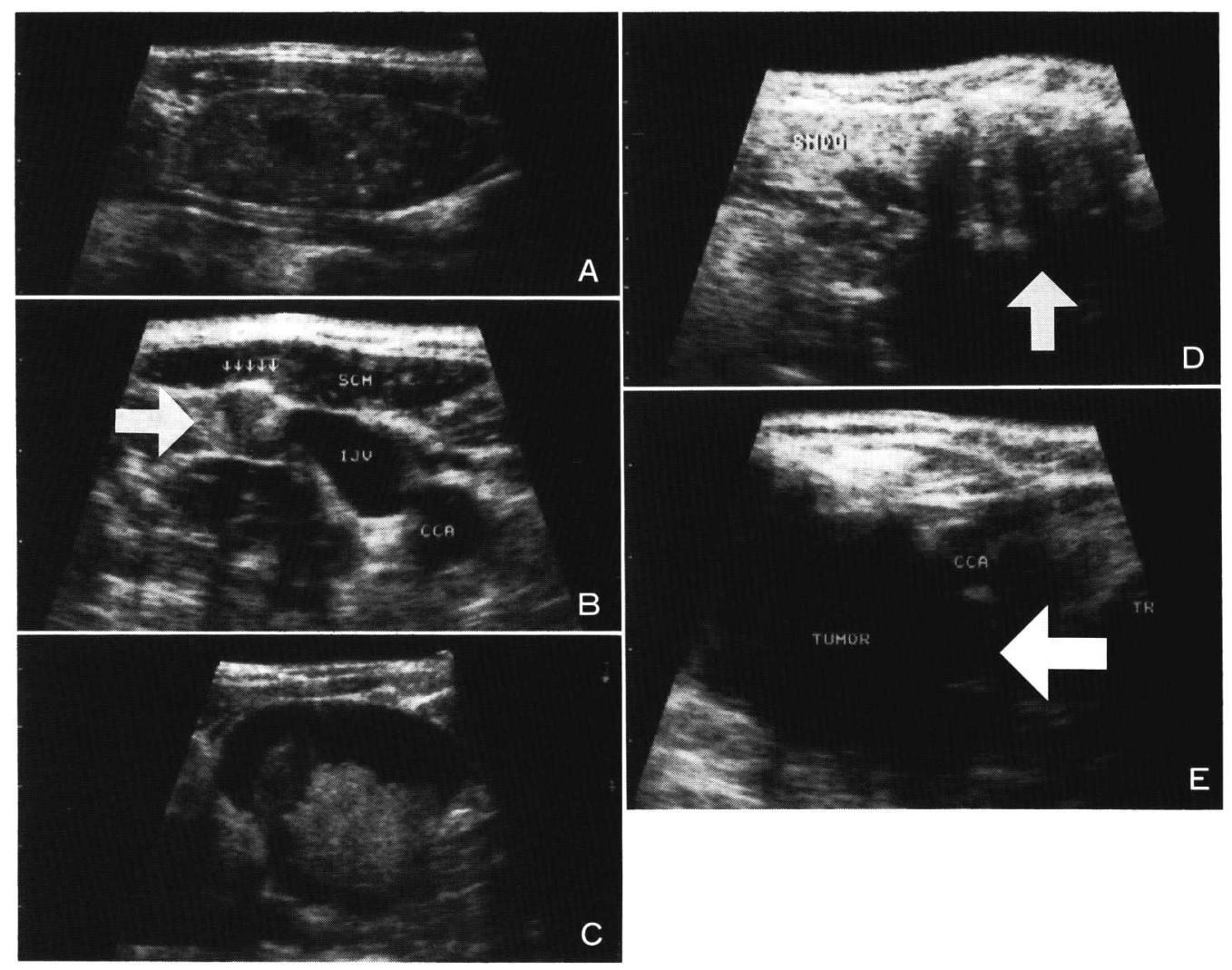

図 1 転移性リンパ節の超音波像

(1)部位, (2)断面, (3)長径, (4)短径, (5)短径/長径比, (6)エコーレベル，(7)点状エコー，(8)線状エコー，

(9)裹胞性パターン。

(A) (1)中内深頸, (2)縦断像, (3) $35 \mathrm{~mm}$, (4) $13 \mathrm{~mm}$, (5) 0.37 , (6)等, (7)あり，(8)なし，(9)あり。

(B) (1)下内深頸 (矢印), (2)横断像, (3) $15 \mathrm{~mm}$, (4) $8 \mathrm{~mm}$, (5) 0.53 , (6)高, (7)あり, (8)なし, (9)なし。

(C) (1)下内深頸, (2)横断像, (3) $60 \mathrm{~mm}$, (4) $42 \mathrm{~mm}$, (5) 0.70 , (6)高, (7)あり, (8)なし, (9)あり。

(D) (1)上内深頸 (矢印), (2)横断像, (3) $23 \mathrm{~mm}$, (4) $13 \mathrm{~mm}$, (5) 0.57 , (6)高, (7)あり, (8)なし, (9)なし。

(E) (1)下内深頸 (矢印), (2)横断像, (3) $35 \mathrm{~mm}$, (4) $25 \mathrm{~mm}$, (5) 0.71 , (6)低, (7)なし, (8)なし, (9)なし。

として短径が有効である対象は, 頭頸部原発悪性腫瘍症 例に限られ，良性疾患は対象外であること，また，悪性 症例を対象とした場合，小リンパ節であっても転移の存 在を完全には否定できないことを常に念頭におく必要が ある。

一方，長径については，斉藤ら゙は，転移性，非転移 性リンパ節間に統計学的な有意差が認められたとしてい るが，本検討では，両者間に有意差は認められなかった。 したがって，長径は質的診断の基準としては不適当であ ると思われる。

2) 形状

唐司ら”は，食道癌の頸部リンパ節の超音波像を検討 して, 短長径比（本検討の短径／長径比にほほ相当する） が転移の鑑別基準として重要であると述べ，長径が 10 $\mathrm{mm}$ 以上で, 短長径比が 0.5 以上であれば転移が示唆さ れるとしている。また，古川も，“厚み”が $6 \mathrm{~mm}$ 末 满のリンパ節であっても，厚み/長径比が 1 に近い場合 は，転移が示唆されると述べている。しかし，良性のリ ンパ節であっても大きい場合は厚み／長径比がしばしば 0.5 以上となることを理由に, 厚み/長径比は一つの目 安であるとして, 診断基準として用いることに注意を促 している ${ }^{11)}$ 。本検討においても，従来の報告 ${ }^{8)}$ と同様に 短径／長径比は転移性リンパ節では, 非転移性リンパ節 より統計学的に有意に $1.00 に$ 近く, 転移性リンパ節の形 状がより球形に近いことが示された。これは，非転移性 リンパ節では，正常の楕円形を保ったまま腫大すること を反映しているのに対し，転移性リンパ節では，短径の 増大が反映されるためであると考えられている ${ }^{12)}$ 。ただ 


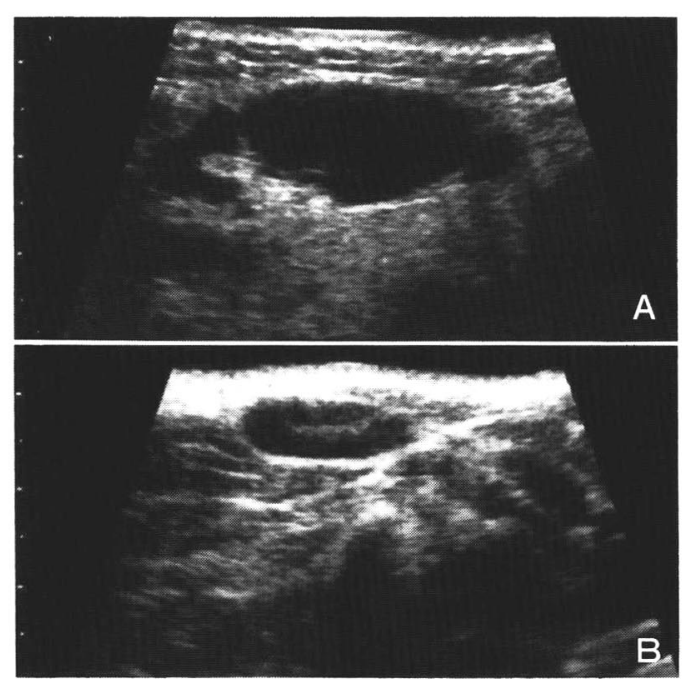

図 2 非転移性リンパ節の超音波像 (1)部位, (2)断面, (3)長径, (4)短径, (5)短径/長径比, (6)エコーレベル, (7)点状エコー, (8)線状エコー, (9) 粪胞性パターン。

(A) (1)顎下, (2)横断像, (3) $23 \mathrm{~mm}$, (4) $12 \mathrm{~mm}$, (5) 0.52 , (6)低, (7)なし, (8)なし, (9)なし。

(B) (1)副神経, (2)縦断像, (3) $20 \mathrm{~mm}$, (4) $7 \mathrm{~mm}$, (5) 0.35 , (6)低, (7)なし, (8)あり, (9)なし。

し, 顎下とオトガイ下リンパ節は非転移性でも球形に近 いことが多い(13)め，同部のリンパ節の形状による質的 診断の際には,この点に注意が必要である。

3) 内部エコー

(1)エコーレベル

今回, われわれは, リンパ節内部のエコーレベルを, 胸鎖乳突筋の横断像のエコーレベルを基準にして高, 等, 低の 3 段階に分類した。このような分類方法は, 定性的 におよそのエコーレベルを評価するためには, 簡単であ り有用であると考えている。

本検討では, 転移性リンパ節では非転移性リンパ節よ り内部エコーレベルの高いものが多い傾向を示していた。 斉藤ら゙は, 内部エコーパターンを 6 型に分類し, そ の病理組織標本を検討している。その結果, 均一高エコー 型（本検討の高ないし等エコーレベルに相当すると思わ れる）を示した転移性リンパ節の 2 例では, 病理組織学 的にリンパ節全体が線維性組織あるいは角化組織によっ て置換されていたと述べている。また，均一低エコー型 （本検討の低エコーレベルに相当すると思われる）を示 した転移性リンパ節では, 腫瘍細胞が, 正常リンパ組織 内に種々の割合で認められたが, 線維性組織や脂肪組織 による置換, また凝固壊死所見は認められなかったと述 ベている。
本検討では, 低エコーレベルは, 非転移性リンパ節の $92 \%$ に認められたのに対し，転移性リンパ節では $13 \%$ にしか認められなかった。したがって, 低エコーレベル は非転移性リンパ節の特徴的な所見であるといえる。

しかし, 低エコーレベルで点状エコーの明らかでない 転移性リンパ節は, 非転移性リンパ節と類似するため鑑 別が難しい。このような場合は, X線 CT, MRI など 他の画像診断も含めて判断するか, 次の段階の検査とし て超音波ガイド下に穿刺吸引細胞診を行なう必要がある。

(2)点状エコー

転移性リンパ節の点状エコーは, 組織学的には, 線維 性組織や壊死組織または角化組織を反映しているといわ れている3 ${ }^{3,1014)}$ 。点状エコーを認めるリンパ節は, 従来, 不均一な内部エコーを呈するタイプとして分類されてい ることが多く，このタイプは転移性リンパ節に多く認め られる所見である ${ }^{3,10)}$ 。古川ら ${ }^{11)}$ は, 転移性リンパ節の 鑑別診断基準として, 点状の内部エコーが均一に存在す ることを挙げている。

本検討でも, 点状エコーは, 転移性リンパ節の $79 \% に$ 認められたのに対し，非転移性には認められなかった。 したがって, 点状エコーが認められれば転移性リンパ節 であるとしてよいと思われる。逆に, 点状エコーが認め られなければ非転移性である可能性が高い。しかし, 転 移性リンパ節の $21 \% に は$ 点状エコーは認められていない ため, 点状エコーの有無による質的診断の際には, この 点に注意が必要である。

(3)線状エコー

Rubaltelli ら 91は, 転移抢よび非転移性リンパ節の 超音波像と組織像を対比して検討し, 線状エコーの存在 は非転移性リンパ節の診断基準となりうると述べている。 斉藤ら ${ }^{3)}$ も, 偏在高エコー型（本検討のエコーレベル低, 線状エコーあり，に相当すると思われる）は非転移性り ンパ節に多く認められたと述べている。本検討において も, 線状エコーは非転移性リンパ節の $58 \%$ に認められた のに対し、転移性リンパ節には認められなかった。した がって, 線状エコーの消失は転移性リンパ節の, また, その存在は非転移性リンパ節の特徵的な所見であるとい えよう。

しかし, 線状エコーは組織学的には, リンパ節門部の 脂肪組織あるいはその境界部の線維性組織を反映してい

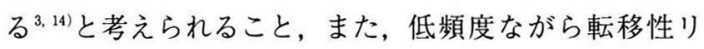
ンパ節においても認められること加か非転移性リンパ 節に特異的な所見とはいえない。したがって, 線状エコー の有無による質的診断の際には，この点に注意が必要で ある。

(4)襄胞性パターン

䡛胞性パターンは組織学的には, 甲状腺乳頭癌では腫 
瘍細胞の産生した粘液を含有する嚢胞であるのに対し， 扁平上皮癌では囊胞様変化を来たした壊死巣である ${ }^{3)}$ と 考えられる。

本検討では，霬胞性パターンは転移性リンパ節の $41 \%$ に認められたのに対し，非転移性では認められなかった。 また，扁平上皮癌での検討では，囊胞性パ夕ーンは転移 性リンパ節の19\%（7/36）に認められている1”。しがっ て, 䡛胞性パターンは転移性リンパ節, とくに甲状腺乳 頭癌の特徵的な所見であるといえる。斉藤ら ${ }^{3)}$ も, 襄胞 合併型は, 全例転移性リンパ節であり, 扁平上皮癌より も甲状腺乳頭癌に多かったと報告している。

しかし，襄胞性パターンは膿瘍を形成するリンパ節炎 にも認められることがあるので注意が必要である6”。

4）扁平上皮癌の転移性リンパ節の超音波像との比較 本検討による甲状腺乳頭癌の転移性リンパ節の超音波 像の特徴は, 大きさと形状, また, 内部エコーのうち点 状および線状エコーについては, 扁平上皮癌の転移性り ンパ節の超音波像の特徴 ${ }^{11}$ とほぼ同様の結果であった。

扁平上皮癌との違いは, 内部エコーのうちエコーレベ ルと暴胞性パターンにみられた。すなわち, 扁平上皮癌 では，等エコーレベル $31 \%(11 / 36)$ ，低エコーレベル69 \% (25/36), 䡛胞性パターン $19 \%(7 / 36)$ であり ${ }^{1)}$, 甲 状腺乳頭癌の転移性リンパ節は, 扁平上皮癌の転移性リ ンパ節より内部エコーレベルの高いものが多く，囊胞性 パターンを認めることが多かった。

\section{結語}

甲状腺乳頭癌における頸部転移性リンパ節39個と良性 疾患の非転移性リンパ節 24 個の超音波像を検討して，以 下の結論が得られた。

1. 転移性リンパ節の短径は, 非転移性より統計学的 に有意に厚かった。

2. 転移性リンパ節の形状は, 非転移性より統計学的 に有意に球形に近似していた。

3. 内部エコーレベルは, 転移性リンパ節では等エコー から高エコーレベルのものが多かったのに対して, 非転 移性リンパ節では, 高エコーレベルのものは認められず, 低エコーレベルものもが多かった。

4. 点状エコーは, 転移性リンパ節では79\%に認めら れたが，非転移性では認められなかった。

5. 線状エコーは，転移性リンパ節では認められなかっ たが，非転移性では $58 \%$ に認められた。

6. 襄胞性パターンは，転移性リンパ節では $41 \%$ に認
められたが，非転移性では認められなかった。

7. 以上の結果から, 甲状腺乳頭癌における頸部リン パ節の超音波像のうち, リンパ節の短径, 形状, 内部工 コーレベル, 点状エコー, 線状エコー, 震胞性パターン は，いずれも質的診断基準の項目とするべきであると考 えられた。しかし，実際の診断に際しては,これらの項 目の所見は総合的に判断する必要がある。

\section{文献}

1) 竹内洋介, 小村 健 他：頭頸部癌頸部転移リンパ 節の超音波像の検討，日耳鼻 $99: 1482,1996$.

2) 古川政樹：超音波診断層法による頭頸部癌の頸部り ンパ節転移の検討，耳鼻 $35: 876-888 ， 1989$.

3) 斉藤泰博, 山田有則他：頭頸部領域における転移 性リンパ節の超音波診断, 超音波医学 $22: 601-610$, 1995.

4) Ishii J. Amagasa T. et al: Ultrasonic evaluation of cervical lymph node metastasis of squamaous cell carcinoma in oral cavity. Bull Tokyo Med Dent Univ $36: 63-67,1989$.

5) Bruneton JN. Roux P. et al: Ear, nose, and throat cancer: Ultrasound diagnosis of metastasis to cervical lymph nodes. Radiology 152: 771-773, 1984.

6) 角田博子, 東野英利子他：甲状腺癌の頸部転移り ンパ節の超音波診断，日超医論文集 51:119-120, 1987.

7）唐司則之, 小野田昌一 他：食道癌頸部リンパ節転 移における超音波断層法の検討, 一短長径比 (S/L) と癌占拠率の関連について一, 超音波医学 14 : 501-509, 1987.

8) Vassallo P. Wernecke K. et al: Differentiation of benign from malignant superficial lymphadenopathy: the role of high-resolution US. Radiology 183:215220,1992

9) Rubaltelli L. Protto E. et al: Sonography of abnormal lymph nodes in vitro: Correlation of sonographic and histologic findings. AJR 155: 1241-1244, 1990.

10）内藤久美子：超音波診断による頸部リンパ節転移の 検討，日本医放会誌 $50: 918-927 ， 1990$.

11）古川政樹, 古川まどか他：頸部リンパ節触診・超 音波検査, JOHNS 10：613-619，1994.

12 ) Sutton RT. Reading CC. et al: US-guided biopsy of neck mass in postoperative management of patients with thyroid cancer. Radiology 168: 769-772, 1988.

13）沼田勉, 鈴木晴彦他：頸部疾患, 金子敏郎 編, 耳鼻咽喉科領域における超音波の情報的応用 157179頁, 1988, 文光堂, 東京.

14) Sakai F. Kiyono K. et al: Ultrasonic evaluation of cervical metastatic lymphadenopathy. J Ultrasound Med $7: 305-310,1988$. 


\title{
ULTRASONOGRAPHIC EVALUATION OF METASTATIC CERVICAL LYMPH NODES IN PAPILLARY CARCINOMA OF THE THYROID GLAND
}

\author{
Yousuke TAKEUCHI, Haruhiko SUZUKI, Ken OMURA, \\ Kazuhiko OKUMURA, Chie YANAI, Tomomi YAMASHITA \\ and Fumiyuki SHIMADA \\ Department of Head and Neck Surgery, Chiba Cancer Center Hospital
}

For the characteristic diagnosis of the cervical lymph node by ultrasonography, we investigated the 39 metastatic lymph nodes in papillary carcinoma of the thyroid gland and 24 nonmetastatic nodes in benign disease with $10 \mathrm{MHz}$ transducer. We examined these nodes on size (long and short axis diameter), shape (short/long axis diameter ratio), and internal echo (echo level, punctate bright echogenic spots, hilus echogenic line, cystic pattern). The short axis diameter and nodal shape of metastatic nodes were more thick and spherical respectively than those of nonmetastatic ones. The internal echo level of the metastatic nodes was more high than the nonmetastatic ones. Of the 39 metastatic nodes, $79 \%$ exhibited punctate bright echogenic spots, on the other hand none of the 24 nonmetastatic nodes showed the spots. Our results indicated that the hilus echogenic line was not present in any metastatic nodes, but was seen $58 \%$ of nonmetastatic ones. Of the 39 metastatic nodes, $41 \%$ exhibited a cystic pattern, none of the 24 nonmetastatic nodes showed a cystic pattern. We think that these different findings between metastatic and nonmetastatic nodes can be valid criteria for the characteristic diagnosis of the cervical lymph node by ultrasonography. 